\title{
Právo, které se nebojí rozhovoru
}

\section{Law Which Does Not Fear Discourse}

\author{
Nad'a Štachová
}

\begin{abstract}
The communication between law and other scientific disciplines is a current topic which is in many aspects characterized by the modern era's search for the lost integrity of knowledge. Manifestations of interdisciplinarity may be found throughout the scientific disciplines, in the practical research of multifaceted topics, and in the theory and philosophy of science. Recognition and credible determination of the boundaries of one's discipline and the finding of ways to cross such lines relates to the recognition of one's own place among the other sciences. Such critical self-examination nevertheless is not possible without studying the history of a particular discipline with a focus on its relation to the other sciences and arts. Therefore, in addition to starting to write history of a particular scientific discipline, in this case law, it is necessary to schematize the specific history of interdisciplinarity. The aim of this article is to present the manner in which law communicated with medicine and philosophy when the sciences of the early modern period started to emerge.
\end{abstract}

KEY WORDS Interdisciplinarity, law, medicine, philosophy, history of law

\section{Úvod}

Právo opět vstupuje do rozhovoru s ostatními obory lidského poznání. V postmoderní situaci se zdá přímo nutností hledat v mnohosti rozrůzněné novověké vědy společnou řeč, odborníci jsou vyzýváni k tomu, aby dovedli před svými vzdálenými kolegy obhájit, čím se zabývají, a to tak, že předmět svého zájmu reprezentují především nadoborovou moudrostí (Pospíšil 2010: 134), již při jeho zkoumání nabyli. Tehdy všichni napjatě naslouchají, jaké slovo zazní. Ale toto napětí a tato pozoruhodná situace dnešní vědy vyplývají z určitého př́iběhu a každý, kdo dnes do interdisciplinárního dialogu vstupuje, by zároveň měl znát jeho dějiny a vývoj, zvláště pak dějiny svého vlastního oboru ve vztazích k oborům ostatním. Proto je třeba začít psát kromě dějin určité vědy, v našem prrípadě práva, i specifické dějiny interdisciplinarity coby fenoménu, který je sice vědomě pěstován a intelektuálně rozvíjen především v posledních desetiletích, nicméně doprovází vývoj vědeckého poznání na jeho cestách od samého počátku. Věda se totiž stává vědou teprve tehdy, když je její jednota a pravda sjednávána dialogicky - s pochopením pro různé, nesrovnatelné způsoby poznání. Úzce vymezené dějiny jednotlivých vědních oborů tento, vědě zcela přirozený, prostor interdisciplinarity sledují většinou jenom tehdy, pokud událost mezioborové spolupráce znamená pro dané obory přímý

Sociální studia. Katedra sociologie FSS MU, 2/2015. S. 27-49. ISSN 1214-813X. 
či neprímý podnět k rozvoji nebo proměně. Dějiny vědy ale nejsou jenom dějinami vědeckých revolucí a pokroku. Dějiny interdisciplinarity proto také nelze jednoduše zúžit pouze na takové události, které spolupracující obory bezprostředně a podstatně proměňují. Jako existují v kuhnovském smyslu období tzv. běžné, normální vědy (normal science) (Kuhn 2008: 23), kdy určitému oboru metodicky, obsahově i sociálně dominuje rozvíjející se paradigma, stejně existuje i běžná komunikace a spolupráce mezi obory, často zprostředkovávaná právě mimooborovými, např́klad uměleckými a literárními, vzory a prostředky. Lze proto důvodně očekávat, že tato bazální interdisciplinární komunikace, živená z vnitřních zdrojů jednotlivých oborů a vyjadřovaná prostřrednictvím obecně sdílené dobové intelektuální kultury, bude hojně dokumentovatelná prameny rozmanitého charakteru, které pro svou myšlenkovou strnulost či „nepokrokovost“ dosud stály spíše stranou pozornosti historiografů vědy.

Jestliže je současná situace vědeckého společenství zatížena novověkou fragmentarizací na vysoce specializované odbornosti a zároveň celkovým rozdělením na tzv. dvě kultury (Snow 1964: 11-12, 59), tj. na humanitní a prrírodovědné obory coby dva svébytné velké okruhy systematického lidského poznání, měli bychom se přirozeně pokusit lépe pochopit, jak oborovou fragmentarizaci a nekompatibilitu obou kultur překonávat smysluplnou komunikací (idea tzv. třetí kultury; Snow 1964: 67). Jednou z cest, které se nám nabízí, je studium modelů interdisciplinární komunikace. Tato studie vychází naznačené snaze vstříc a zaměřuje svou pozornost primárně na období raného novověku, kdy se budoucí rozdrobenost a nekomunikativnost vědeckých specializací teprve rodila. Přitom nás bude především zajímat, jaké místo v dobové bazální interdisciplinární komunikaci zastávalo právo.

Dílo, z něhož budeme níže vycházet a které svědčí o rozvíjení dialogu práva s ostatními vědami a o jeho místě v tomto společenství, je spis raně novověkého českého prokurátora a humanistického básníka Michala Pěčky z Radostic (1575/1576-1623) nazvaný Akcí a rozepře mezi filozofem, $v$ lékařství doktorem a orátorem aneb prokurátorem, třmi vlastními bratry $^{2}$ Pěčkou rozehraný dialog filozofa, lékaře a orátora aneb prokurátora je nesen základní, dodnes aktuální otázkou, který z těchto tradičních oborů je společnosti prospěšnější a proč. Kritickou analýzou textu se pokusíme rozkrýt tajemství Pěčkovy ne př́liš překvapivé odpovědi stranící prokurátorům. Za zdánlivě povrchním soudem lze zachytit pro právo charakteristický způsob řeči, umění slova a výmluvnosti, od jehož zvládnutí či nezvládnutí se odvíjí úspěšnost i prospěšnost práva $v$ různorodém společenství ostatních věd.

\footnotetext{
Základní informace o autorovi přináší Truhlář et al. (1973: 123-132). Nejnověji na Pěčkovu osobnost upozornil Pišna (2007, 2013: 215-223).

2 Celý název v transliterované podobě zní: Akcy a Rozepre Mezy Filozoffem, w Lékařstwij Doktorem, a Orátorem aneb Prokurátorem Třmi wl'astnjmi Bratry, Kterýby z nich Obcy a Wl'asti swé neypl'atněgssý a neyvžitečněgssý býti a tak wedlé Kssafftu Otcowského dwau djlu Statku po něm dostati mél. Yak Včeným a Maudrým tak y Prokurátorům weyml’uwným a wssechněm Lidem Obcy a Wlasti swé slaužjcým mil'á, prospěssná, a vžitečná. Wydaná od Michal'a Piečky Smržického z Radostic (Wytisstěno w Starém Městě Pražském v Pawla Sessya 1609). V textu budeme dále používat pouze zkrácenou verzi Akcí a rozepře a v poznámkách odkazovat na stránkové kustody, nebot' dílo není paginováno. Pro analýzu jsme používali exemplář uložený v Moravské zemské knihovně v Brně pod sig. ST1-0024.998. Popis tisku přináší Horák (1956: 141).
} 
Postupovat budeme tak, že nejprve pro účely historického zkoumání blíže vymezíme pojem interdisciplinarity. Následně alespoň stručně načrtneme její dějiny, které tvoří vývojový kontext vlastního jádra naší práce, spočívajícího jednak v rozboru Pěčkova díla $A k c i$ a rozepre, kdy se z pozic právní historie pokusíme vymezit dobový polemický a apologetický způsob konfrontace práva, medicíny a filozofie, jednak v identifikaci raně novověkých modelů interdisciplinární komunikace tř́ zmíněných oborů, které se v tomto díle projevují. Závěrečné shrnutí bude směřovat ke zhodnocení těchto modelů vzhledem k dobovému intelektuálnímu kontextu i vzhledem k současným snahám o překonání novověké oborové fragmentarizace.

\section{Pojem interdisciplinarity}

O interdisciplinaritě̉ se dnes v akademickém prostředí stále častěji hovoří. Mnohdy se stává př́mo nutnou součástí komplexních badatelských záměrů, avšak často není zcela jasné, co se tímto pojmem ve skutečnosti míní. Snadno se tudíž může stát, že se pojem interdisciplinarity zredukuje na pouhou módní instrumentální akademickou frázi. I pro sám teoretický vývoj moderního konceptu interdisciplinarity platí, že neexistuje jedna za všech okolností použitelná definice ${ }^{4}$ (Klein 1990: 12), přestože se minimálně od druhé poloviny 20. století objevují pokusy pojem interdisciplinarity jednotně uchopit. Interdisciplinarita se proto převážně vymezuje čtyřmi způsoby (Klein 1990: 55): pomocí př́kladů, motivace, principů vzájemné interakce a terminologické hierarchie. Skrze př́klady se demonstruje konkrétní podoba interdisciplinárních aktivit, motivace vysvětluje, proč se tyto činnosti vủbec uskutečňují, vzájemné interakce ukazují proces spolupráce zapojených věd a konečně terminologická hierarchie odlišuje různé úrovně oborové terminologické integrace. Kromě těchto standardních vymezení se dnes interdisciplinarita definuje také vzhledem k pojmům multidisciplinarity a transdisciplinarity ${ }^{5}$ Zatímco multidisciplinarita počítá s přítomností a koexistencí více oborů, aniž by se vzájemně prolínaly a setkávaly, interdisciplinarita vychází z aktivně rozvíjených vztahů spolupráce či reflexe mezi vědami. Transdisciplinarita potom svými tématy překračuje samotné hranice oborů a snaží se o nahlédnutí nové jednoty poznání, která odpovídá jednotě skutečnosti.

Pro účely historického zkoumání zaměřeného na dějiny interdisciplinarity v raně novověké éře by bylo anachronické, kdybychom jednoduše uvedené moderní vymezení konceptu interdisciplinarity převzali. S jistou dávkou obezřetnosti je však můžeme chápat jako

3 Od poslední dekády 20. století narůstá sekundární literatura exponenciální řadou. „Klasickou“ syntézu představuje práce Klein (1990). Táž se podílela i na př́pravě výše citované kolektivní monografie (Frodeman, Klein a Mitcham 2010), v níž je uvedena další literatura. Z německy mluvícího prostředí uvádíme výběrově dva svazky Internationales Jahrbuch für interdisziplinäre Forschung (Schwarz 1974, 1975), speciální číslo časopisu Das Mittelalter (1999) věnované interdisciplinaritě a využití tohoto konceptu pro medievistiku, v němž je shrnuta starší literatura, a vídeňský sborník (Lenz 2010).

4 Definici interdisciplinarity poprvé širší veřejnosti představil Jantsch (1970).

5 Definice všech tří pojmů, včetně etymologie, podává David Alvargonzález (2011). V českém prostředí uvedené pojmy vysvětluje Ivan M. Havel (1998: 137-138, 2005: 2-3). 
vymezení předběžné, které zůstává otevřené i jiným podobám vztahů mezi vědami, než jaké známe ze současnosti. Termín interdisciplinarita proto budeme používat v co nejširším slova smyslu, tj. jako dějinný fenomén spočívající ve vědomém navazování vztahů či reflexi těchto vztahů mezi vědními obory a uměními. Přitom největší důraz je třeba $\mathrm{v}$ prrípadě dějinného zkoumání klást na bazální komunikativní rovinu vztahů mezi učenci jakožto zástupci jednotlivých oborů lidského poznání dané doby, jejichž písemně podchycenou komunikaci nejvěrněji odráží dostupná pramenná základna, at' už ve formě korespondence, či jiné umělecké i odborné, literární tvorby.

\section{Právo a dějiny interdisciplinarity ${ }^{6}$}

Byla to totiž právě čilá osobní i zprostředkovaná komunikace učenců zastávajících různé názory a perspektivy, která charakterizovala celý vývoj evropské vzdělanosti od starého Řecka až po současnost. Ochota vstoupit do intelektuálního dialogu, společně v něm hledat pravdu o povaze skutečnosti a jevů, touha se sdružovat ve školách, knihovnách a jiných institucích či odvaha se vzájemně stýkat a potýkat napříč jednotlivými školami a myšlenkovými směry zásadním zpo̊sobem spoluvytvářely tradici evropských věd. Přitom lze vzhledem $\mathrm{k}$ našemu tématu, jímž je specifický problém práva v mezioborovém dialogu, jistě pokládat za historicky věrohodné takové chápání práva, které je s vývojem tohoto tradičního komunikativního společenství věd spojuje. Přes značnou oborovou autonomii a specifika související primárně s pragmatickou úlohou práva ve společnosti nelze právo jednoduše z tohoto širšího rámce vyjmout. Proto při psaní dějin práva vystupujícího v dialogu s ostatními vědami musíme nejprve alespoň stručně sledovat dějiny samotné jednoty věd a toho, jak byla tato jednota $\mathrm{v}$ různých obdobích znovu teoreticky hledána i prakticky, komunikativně sjednávána, tj. dějiny interdisciplinarity.

Od nejstarších dob platí za základní přesvědčení to, že veškeré lidské poznání tvoří jednotu a že tato jednota odráží jednotu bytí (Husserl 1996: 31). U zrodu uvedeného univerzalistického náhledu stálo filozofické myšlení antického Řecka (především v osobách Platóna a Aristotela), které jednotu poznání spojovalo s filozofií a se svobodnou diskusí filozofů hledajících pravdu ve vzájemném setkávání, střetávání a rozhovoru. Dějiny interdisciplinarity se však neutvářely pouze kolem filozofických idejí univerzality, jednoty a dialogu, které stále zaznívají i v moderním diskursu, nebot' jsou v platónském smyslu věčné a nadčasové (Klein 1990: 19). Svoji roli sehrával rovněž systém vzdělávání, jemuž ve starověkém Rímě dominovala rétorika odpovídající ideálu výmluvného občana, který se nejen zajímá o věci veřejné, ale zároveň o nich patřičně diskutuje. Mnohými antickými autory byla však

6 Dějinám interdisciplinarity bývá $\mathrm{v}$ rámci literatury týkající se teoretických základů interdisciplinarity a její praktické aplikace věnována menší pozornost. Aktivity na tomto poli rozvíjí od roku 2008 Center for the Study of Interdisciplinarity. Z nejnovější literatury zmiňme alespoň příspěvek od Petera Weingarta (2010) pro The Oxford Handbook of Interdisciplinarity (Frodeman, Klein a Mitcham 2010). Interdisciplinární spolupráci mezi středověkou filozofií a teologií se věnuje Rolf Darge (2010). Za cenné podněty, rady a připomínky k úvodním částem příspěvku děkuji Eduardu Fiedlerovi. 
tato prríliš těsná vazba vzdělávacího systému na řečnické umění vnímána jako nedostatečná a v úsilí o jednotu poznání selhávající. Středověká univerzita navazující na starší tradici katedrálních škol ${ }^{7}$ rétoriku začlenila do širšího rámce sedmera svobodných umění a zároveň poskytla nový svobodný prostor pro její uplatnění při pravidelných učených disputacích. Vedle proklamované jednoty umění a věd (universitas scientiarum) univerzitu utvářela také jednota učitelů a žáků (universitas magistrorum et scholarium) ${ }^{8}$, kteří měli být uvedeni do společných základů jednotlivých umění a v jejich rámci potom pěstovat určitou specializaci. Používal-li se v pozdním středověku termín „disciplína“, býval spojován primárně s teologií, filozofií, právem či medicínou. Tomuto dělení ostatně odpovídalo odborné zaměření nejstarších evropských univerzit v Pař́ží, Boloni a Salernu ${ }^{9}$ Je důležité si uvědomit, že tlak na specializaci $v$ rámci jednotlivých fakult, zejména právnické a lékařské, vycházel od 14. století primárně zvenčí ze strany vládních a profesních kruhů, případně duchovenstva. $\mathrm{V}$ důsledku tohoto tlaku se univerzity často ocitaly v duchovní krizi, jako korporace upadaly na úroveň cechovního zř́zení a vzdalovaly se původní ideji ${ }^{10}$ středověké univerzity (Dubský 1993: 73). Učené zájmy, tvořivé intelektuální prostředí, komunikační otevřenost a poctivost realizované prostřednictvím disputací a konečně snaha o celkovost - obracení se k Jednomu (ad Unum vertere $)^{11}$, které stály u jejich zrodu, ustoupily proudům myšlení vznikajícím vně scholastických univerzit, zejména na italské půdě (Le Goff 1999: 129-139).

Éra renesance a humanismu zprostředkující dědictví antiky představovala zvláštní kapitolu v dějinách interdisciplinarity. Nový směr předznamenávala od konce 13. století pozvolná dezintegrace sedmera svobodných umění coby hierarchické struktury poznání odrážející strukturu stvořené skutečnosti. Nastupující renesanční pojetí vědy založené na otevřenosti k př́rodně filozofickým otázkám a ke zkušenostnímu poznání tuto skutečnost promýšlelo perspektivou různých vědních disciplín, které se vzájemně překrývaly a doplňovaly (Petrů 1996: 227-228). Renesančním ideálem se nyní stal univerzální učenec-umělec (uomo universale), který svoje vzdělání a zběhlost $\mathrm{v}$ mnohosti oborů dokázal přetavit $\mathrm{v}$ jednotu výjimečného tvưrčího aktu (Burke 2007: 105). Příkladem takového tvůrčího aktu mohla být např. kopule Svatopetrského dómu nebo krásná a smysluplná řeč, kterou pronášel ctnostný a v mnoha vědách učený řečník (orator bonus, orator doctus) ztělesňující humanistický ideál

$7 \quad$ K vývoji předcházejícímu vzniku prvních univerzit srov. alespoň Riché a Verger (2011), zejména I. část práce.

8 Oba pojmy vymezují charakteristické znaky univerzit. K živé ideji patřila navíc libertas scholastica - idea svobody. Blíže ke všem třem pojmům viz Petráň (1993: 96-99).

9 Literatura k dějinám univerzit je velmi bohatá. Základní orientaci po starší i novější literatuře, ovšem s akcentem na dění v Říši, přináší pro období 15.-17. století Hammerstein (2003). Výběrově odkazujeme též na první dva svazky prestižní kolektivní monografie (De Ridder-Symoens a Rüegg 1992, 1996). K počátkům středověkých univerzit, se zvláštním zřetelem na vývoj v Boloni a Paříži, srov. Grundmann (1976).

10 V našem prostředí paradoxně méně známý, s ohledem na dobu vzniku ovšem jedinečný sborník, který vyvolal pozitivní ohlasy v zahraničí, prredstavuje soubor statí k ideji univerzity, které jsou stále inspirativní (Fiala 1993).

11 Zdeněk Neubauer (1993: 118) vykládá smysl slova universitas jako celkovost, nikoliv veškerost. 
znovuobjevených spisů Ciceronových a Quintiliánových ${ }^{12}$. K témuž ideálu se ostatně vztahoval také autor textu Akci a rozepře, který budeme v této studii analyzovat, Michal Pěčka $\mathrm{z}$ Radostic.

Paralelním jevem individuálního renesančního polyhistorství (více oborů se stýká v jednom výjimečném a ctnostném člověku) byla stále intenzivnější sociálně motivovaná humanistická komunikace, připomínající, podobně jako v této době znovu ožívající rétorika, hru s předem stanovenými pravidly (Storchová 2003b: 150). Sít' vztahů budovaná zejména prostřednictvím epistolografie mezi jednotlivými humanistickými centry představovala komunikační pole ${ }^{13}$, $\mathrm{v}$ jehož rámci docházelo $\mathrm{k}$ čilé učenecké výměně a vzniku nového, bazálním formám interdisciplinárního dialogu otevřeného, intelektuálního společenství. Pro vstup do tohoto humanistického komunikačního pole však muselo být splněno hned několik předpokladů. Bez jazykové kompetence a znalosti antické časomíry nemohl jedinec komunikaci rozumět a bez dodržení předepsané a očekávané formy a obsahu ji nemohl platně rozvíjet. Svou roli zde nepochybně sehrálo nebývalé rozšíření knihtisku, který zajistil snadnou cirkulaci tištěného media, a tím vlastně umožnil nástup nového komunikačního systému, jenž byl založen na intelektuálním sdílení textů nejrůznějšího zaměření (Storchová 2003a: 62-67).

I přes tento pozoruhodný vzmach humanistické vzdělanosti spojené s literární kulturou raného novověku se jako určující pro formování novověkého vědeckého obrazu světa ukázala být geometrizace přirozeného prostoru a matematizace př́rodních věd spojená s filozoficky zdůvodněnou proměnou jejich metodologie (Galileo, Bacon, Descartes) (Horský 2013). Nikoli tedy duch literární, ale duch geometrický a matematický se stal obecně přijímaným vzorem vědeckosti a zárukou pravdivého poznání (Husserl 1996: 43-81) a jeho nové jednoty (Vopěnka 2003: 592, 640). Je pozoruhodné, že i v tomto procesu sehrálo svoji úlohu právo, byt' již nikoli ve spojení $\mathrm{s}$ rétorikou. Nároky kladené $\mathrm{v}$ tzv. inkvizičním (vyhledávacím) procesu na relevanci důkazních prostředků, důraz na empirické svědecké výpovědi a metafory výslechu a prírodních zákonů patřily $\mathrm{k}$ inspiračním zdrojům novověké vědecké metody a zároveň zdrojům důvěry $\mathrm{v}$ její legitimitu a objektivitu (Burke 2007: 234-235). Přitom podobně jako $\mathrm{v}$ právu byl i $\mathrm{v}$ novověkých přírodních vědách pocit’ován jako zásadní problém jazyka a jeho korespondence se skutečností. Novému, jasnému a přesnému poznání měl sloužit univerzální jazyk, jak jej v různých podobách navrhovali v období raného novověku např. Descartes, Komenský i Leibniz. Jeho ustavením by odpadla obtíž nejednotné vědecké terminologie či jejího nedůsledného používání a značně by se usnadnila veškerá interdisciplinární spolupráce. Protože se však žádný z těchto projektů univerzálního jazyka neuskutečnil, začala v očích vědecké komunity plnit jeho úlohu právě matematika.

12 Charakteristiku učeného orátora v ciceronském duchu popisuje Klein (1990: 23). O ve své době senzačních objevech kompletních Základů rétoriky Marca Fabia Quintiliana a souboru ciceronián se zmiňuje Jiř́i Kraus v předmluvě českého překladu (Quintilianus 1985: 17). Oba nálezy zásadním způsobem ovlivnily dějiny rétoriky a vyvolaly zvýšený zájem o řečnické umění.

13 Koncept literárního pole nově modifikovaný s ohledem na formalizovaný diskursivní modus ve vztahu k latinskému renesančnímu humanismu nejnověji použila Storchová (2011). Jejího konceptu se přidržujeme i v našem příspěvku. 
Jak patrno, již na počátku novověku se rýsuje, byt' prozatím skrytě, budoucí problém tzv. dvou kultur, o nichž jsme hovořili výše. Nová prrírodní filozofie čerpající z novoplatónských idejí spolu se vznikající empirickou a kalkulující novověkou vědou odpovídají v tomto smyslu současné kultuře přírodních věd a literární humanismus naopak kultuře věd humanitních (Yatesová 2009: 168-175). Toto základní rozštěpení evropské vzdělanosti je navíc v novověku umocněno rostoucí fragmentarizací jednotlivých oborů, která postupem času učinila interdisciplinární vztahy a bazální komunikaci mezi odborníky různých specializací velmi obtížnou, ba místy téměř nemožnou.

Tyto negativní projevy výše nastíněného vývoje se však měly projevit a být teoreticky reflektovány především teprve v průběhu 20. století. V době kolem roku 1609, kdy náš autor Michal Pěčka z Radostic vydává spis Akci a rozepre, ještě takováto striktní oborová vyhraněnost neexistovala. Právník mohl být zároveň básníkem, lékařem, astronomem nebo botanikem. Jasná a neprostupná vymezení oborových polí a kompetencí prozatím nebyla ustavena, což je dobře patrné na ideové pestrosti renesanční přírodovědy a př́rodní filozofie, která se prostřednictvím mimořádných osobností, jako byli Tadeáš Hájek z Hájku, Jan Jessenius, Johannes Kepler, Tycho de Brahe a další, právě v Pěčkově době plně zabydluje v Praze ve spojitosti s mecenášstvím a podporou císaře Rudolfa II. (Horský 1980: 12-43). Z hlediska vývoje vědy odpovídá toto období tzv. před-paradigmatickému stavu (Kuhn 2008: 29), kdy vedle sebe paralelně vzniká mnoho různých škol a př́stupů k výzvám doby. Na druhou stranu se všechny tyto jedinečné a zvláštní př́istupy mohou v námi zkoumaném období vzájemně setkat $\mathrm{v}$ rámci toho, co již pevně ustaveno bylo, $\mathrm{tj}$. $\mathrm{v}$ rámci onoho literárního komunikačního pole raně novověkého učeného společenství humanistů.

\section{Pěčka jako autor Akcí a rozepře}

Ve druhé polovině 16 . století, tedy v době, kdy Pěčka poprvé vstupuje na půdu nižších nekatolických škol, již není humanismus v českých zemích záležitostí několika elitních kroužků intelektuálů, ale ideovým proudem zasahujícím rovněž, zpočátku jinak konzervativní, prostředí pražské utrakvistické univerzity ${ }^{14}$ (Pešek 1995b: 227-231). Gramotnost přestává být výsadou úzké vrstvy vzdělanců, poptávka po vzdělání v humanistickém duchu roste a stává se společenskou nutností, otázkou seberealizace i reprezentace (Pešek 1993: 27-28). Nepřekvapí proto, že Pěčka jako syn významného chrudimského měštana je $\mathrm{v}$ duchu tehdejšího masového trendu posílat mládež za vzděláním nejčastěji na některou z místních partikulárních škol směřován nevlastním otcem Duchoslavem Tugurinem Čáslavským nejprve na luteránské gymnázium do Valašského Meziříčí, později do slezské Vratislavi, uherského Jageru a následně do saského Freiberku. Oproti svým méně movitým vrstevníkům má Pěčka tu nesrovnatelnou výhodu, že může během krátkého rozpětí několika let navštívit řadu předních evropských učilišt' v cizině, kromě výše jmenovaných navíc proslulé gymnázium illustre

14 Vztah pražské univerzity k humanismu prošel několika etapami - k tomu blíže srv. Svatoš (1988). 
Johanna Sturma ve Štrasburku ${ }^{15}$. V jubilejním roce 1600 se vypraví do Neapole a při té př́ležitosti se stihne zastavit pravděpodobně také v Římě (Martínek 1972: 115-117).

Právě zahraniční studia mají na Pěčku zásadní vliv (Martínek 1983-1984: 118), at' už jde o jeho první setkání s katolickým prostředím v průběhu italské cesty, uvědomění si permanentně přítomného tureckého nebezpečí, které pocítil na vlastní kủži v Turky obleženém Jageru, nebo možnost srovnávat vzdělanostní a kulturní úroveň doma i v zahraničí. Hojné pobyty v cizině Pěčku utvrzují v přesvědčení o zaostalosti domácího kulturního prostředí, jež se stává terčem jeho nevybíravé kritiky prostupující převážnou část jeho před- i pobělohorské tvorby. K pozdejjšímu rozhodnutí opustit protestantský tábor a konvertovat tajně ke katolíkủm ${ }^{16}$ přispějí výrazně rovněž zážitky z cest. Konečně pod vlivem učené disputace, jíž je Pěčka př́tomen na studiích ve Štrasburku ${ }^{17}$, sestavuje dílo, o němž pojednává tato studie.

Výše uvedené stručné poznámky nám měly umožnit sledovat faktory, které působily na Pěčkův duchovní a intelektuální vývoj, jenž nebyl rozhodně přímočarý. Víme už, že Pěčka absolvoval řadu zahraničních studijních pobytů, převážně v protestantských, německy mluvících oblastech. Na české prostředí však úplně nezanevřel. V roce 1598 se nechává zapsat do Nazaretské koleje v Praze, snad s vidinou snadného zisku hodnosti bakaláře svobodných umění (Martínek 1972: 112, 116). Jako člen pražské literární obce spjaté s univerzitou se na čas zapojuje do jejího komunikačního pole a získává si postupně obdiv současníků. $\mathrm{O}$ úspěchu Pěčkovy strategie v budování vlastního statusu v komunitě humanistů svědčí mj. průvodní básně talentovaných Pěčkových přátel - Alžběty Johanny Westonie a Jana Campana Vodňanského, které vložili do Akcí a rozepře. Kromě vlivných básníků upevňuje Pěčka formou dedikačních př́íisů kontakty s předními domácími aristokraty, své básně věnuje také císaři a papeži. Z této linie nevybočuje ani Akci a rozepre, jež je uvozena dvanácti dedikačními listy českých šlechticů a erbovních měštanů, o jejichž přízeň Pěčka usiluje.

Jakákoliv forma komunikace např́íc celoevropskou obcí humanistických vzdělanců je ovšem podmíněna jazykovou vybaveností a úrovní humanitního vzdělání zainteresovaných jedinců. Proniknout do dobové res publica litteraria pro Pěčku znamená ovládat brilantně latinu, př́ípadně základy dalších jazyků. Rozvíjení elegantní komunikace nutně vyžaduje znalost rétoriky, antické metriky i antických literárních vzorů a autorit (Storchová 2003b: 151-152). Dobrou jazykovou a nábožensko-etickou průpravu Pěčkovi poskytují gymnázia,

15 Studijní plán výuky na štrasburském gymnáziu, jemuž na přelomu 16. a 17. století dominovala rétorika, přehledně sestavila Juřicová (2008: 51-57).

16 Stalo se tak někdy před rokem 1617. Obrat ve věcech víry měl zásadní vliv na pozdější Pěčkovu kariéru. Důvodem ke konverzi nebylo přesvědčení o správnosti katolických dogmat, ale pohrdání a nenávist k české zemi a jejím obyvatelům (Martínek 1983-1984: 122).

17 Písemně zachycenou podobu disputace přináší štrasburský tisk Orationes XI. de comparatione medici, philosophi et oratoris: exercitii gratia Argentinensi in academia scriptae ac recitatae Anno M. DC. Ab Domino Carolo L. barone de Kittlitz, in Malnitz et Eisenberg et aliis nobilibvs adolescentibvs, eloqventiae stvdiosis. Argentinae: Typis Iosiae Rihelii, per Andream Rietschium, 1600, který řeší podobně jako Akci a rozepre spor o to, kdo je ze tří bratř́i vlasti nejprospěšnější. Rozprava je však koncipována odlišně než u Pěčky, nebot' je rozdělena mezi 11 různých mluvčích. V řadě ohledů se Pěčka nechal štrasburskou disputací inspirovat, není však na ní otrocky závislý. 
určitou formu nadstavby pak představuje pobyt na pražské univerzitě, kde je sice stále udržována kontinuita se středověkem prostřednictvím četby Aristotelových spisů, v rámci sedmera svobodných umění je však ve druhé polovině 16 . století položen větší důraz namísto logiky na morální a př́rodní filozofii a zejména rétoriku (Pešek 1995b: 231). Zbývá ještě doplnit, kde se Pěčkovi jako činnému prokurátorovi dostává právnického vzdělání. Neexistence vysokého právnického učení v českých zemích i zmínek o právní propedeutice ve školních řádech městských škol, zdá se, potvrzuje myšlenku, že adepti právnických profesí si musí vystačit se samostudiem a praxí, pro kterou ostatně rozvíjející se správní aparát měst skýtá dostatek př́ležitostí (Pešek 1993: 50).

Humanistické vzdělání, hojné zkušenosti ze zahraničí i studiu nakloněné rodinné zázemí dokáže Pěčka velmi dobře zúročit. Na počátku 17. století má již své pevné místo v humanistické obci literátů. Svou píli ovšem neupíná pouze k poezii, jak dokládá spis Akci a rozeprée, který sice Pěčka doplňuje několika latinskými distichy, dedikace i zvolený syžet však prozrazují Pěčkovy ambice proniknout na prahu své profesní kariéry mezi prokurátory s tématem, které ovšem právní prostředí přesahuje a svědčí o dobové nutnosti v rozhovoru s ostatními tradičními disciplínami opět hájit prospěšnost a nobilitu práva.

\section{Charakteristika Akcí a rozepře}

Když v roce 1609 nechává Pěčka vydat v pražské Sessiově tiskárně dílo Akcí a rozepře, je již jako erbovní měšt’an dobře majetkově zajištěn ${ }^{18} \mathrm{a}$ jeho jmění má být v pozdějších letech výrazně rozmnoženo $\mathrm{v}$ souvislosti $\mathrm{s}$ bělohorskou porážkou, kdy se jako straník císaře, jezuitů a Karla z Lichtensteina stává správcem statků zrušené pražské akademie a soudcem nad účastníky stavovského povstání (Truhlář et al. 1973: 123). Na počátku 17. století však teprve začíná, na rozdíl od svého literárního působení, pronikat mezi ty, jimž je věnována $A k c i$ a rozepre, tedy „všechněm při vyšších soudech Království českého na hradě Pražském... prokurátorům“ (Pěčka 1609: B1a). Zdá se, že volba češtiny jako hlavního jazyka spisu, stejně jako uvedená korporativní dedikace jsou nepř́mými indiciemi pro to, abychom spis $A k c i$ a rozepře považovali za Pěčkův pokus, plně v intencích našich poznámek o humanistické komunikaci, oslovit a oslavit profesi prokurátorů a poskytnout jim argumentační výzbroj pro př́ípad pochybností o užitečnosti a prospěšnosti tohoto povolání (Pišna 2013: 222).

Ústřední otázkou, kolem které osciluje Pěčkův text, je již naznačená společenská prospěšnost jednotlivých odborností filozofa, lékaře a řečníka-prokurátora ${ }^{19}$. O původní otázku v humanistickém prostředí ovšem nejde, jak dokládá srovnání Akci a rozepre s předlohami, z nichž Pěčka vychází ${ }^{20}$. Vědomá vázanost na cizí vzory, práce se soubory citátů spíše než

18 O Pěčkovi víme z toho období pouze tolik, že získal slušný majetek sňatkem a dědictvím, zakoupil se na Novém Městě pražském a vykonával advokátskou praxi (Truhlář et al. 1973: 123).

19 K terminologii a náplni činnosti řečníků a prokurátorů ve středověku a raném novověku pro české poměry srov. Bláhová (2009).

20 Kromě výše uvedeného štrasburského tisku (pozn. 17) je další předlohou, z níž Pěčka s velkou pravděpodobností čerpal, spis Filipa Beroalda staršího (1453-1505) Philippi Beroaldi opusculum eruditum quo continetur Declamatio Philosophi, Medici et Oratoris de excelle[n]tia discepta[ntiu[m] 
s originálními texty antických autorů, využití oblíbené formy dialogu, to vše představuje v podmínkách českého humanismu běžný jev, s nímž je možno se setkat i u jiných autorů (Varcl 1978: zejm. 207-250). Přesto nelze Pěčkovi upřít zásluhu na tom, že recepcí zahraničních témat konfrontuje domácí kulturní a intelektuální prostředí s nutností čelit otázkám a pochybám stran etického výkonu profese, a zejména stran nesamozřejmosti postavení jednotlivých tradičně dominantních odborností ve společnosti, která je vnitřně obohacována novými výraznými intelektuálními impulsy (heliocentrismus, první pitva v Praze, zámořské objevy atd.) a zároveň zkoušena náboženskými, kulturními i vědeckými dobovými spory. V tomto smyslu přebíranou látku Pěčka na některých místech upravuje pro české poměry a dodává jí na společenské aktuálnosti.

Rozvrh Akcí a rozepre Pěčka koncipuje v duchu výše zmíněné předlohy Filipa Beroalda, struktura proto plně odpovídá názvu díla, v němž klíčovou roli sehrávají tři vlastní bratři (filozof, lékař a orátor neboli prokurátor) vedoucí před sborem soudců spor o čtvrtý díl dědictví po zemřelém otci ${ }^{21}$. Právě jejich obhajoby a vzájemné invektivy pronesené za účelem vítězství ve při, které na sebe navazují v pořadí filozof, lékař a orátor neboli prokurátor, představují vlastní jádro a zároveň nejobsáhlejší část Akcí a rozepře. Bratři však ve svých řečech nehájí jenom svůj soukromý zájem, nýbrž sám původ, čest, legitimitu a slávu svých odborností, praktickou i teoretickou rovinu svých věd, jejich místo ve společnosti a mezi ostatními vědami. Vzájemně se při tom napadají a provokují, chtíce jeden druhého převýšit, ponížit či usadit. Tento dramatický zápas o legitimitu oborů budeme v naší analýze sledovat, protože se domníváme, že k dějinám vztahů mezi vědami, tj. k dějinám interdisciplinarity v širším slova smyslu, přirozeně patř́i. ${ }^{22}$

Jednotlivé promluvy od nejstaršího k nejmladšímu z bratří podřizuje Pěčka vždy totožnému schématu. Každý z bratří začíná obhajobou své odbornosti, kritizuje ostatní disciplíny, argumentuje v jejich neprospěch a obecně se snaží vyzdvihnout vlastní silné stránky a naopak zvýraznit negativa zbývajících dvou bratří. V následujícím rozboru se pokusíme nastíněnou rozpravu rekonstruovat především z té perspektivy, kterou jsme si dějinně i ideově vymezili $\mathrm{v}$ úvodních částech tohoto př́spěvku, tj. z perspektivy, která sleduje primárně dobové vztahy práva $\mathrm{k}$ ostatním dvěma oborům. To nám umožní identifikovat raně novověké modely interdisciplinární komunikace, na které se podílelo svým jedinečným způsobem právě právo.

et libellus de optimo status [et] principe. Bononiae: Benedictus Hectoris [Faelli], 1497. Již z jeho názvu je patrné, že Beroaldus látku rozvrhuje stejně jako Pěčka, dokonce obhajoby, které jsou však podstatně stručnější než v Akci a rozepre, zaznívají ve stejném pořadí filozof, lékař, orátor. Vztah mezi citovanými předlohami a Akci a rozepře však nebyl dosud dostatečně objasněn.

Syžet, v němž se poprvé objevuje spor mezi třemi bratry o čtvrtý díl dědictví po otci, odkazuje k 7. knize Quintiliánových Základů rétoriky (Pěčka 1609: B8a).

22 Humanistické spory o přednost jednotlivých věd, které v italském prostředí mapují podrobně Lynn Thorndike a Eugenio Garin, nebyly jevem vzácným. Jako pars pro toto uvádíme např. spor o přednost vedený mezi právem a medicínou, o němž v roce 1399 pojednal Coluccio Salutati (1990). Je otázkou, zda za sporem mezi artisty a právníky probíhajícím krátce po založení Karlovy univerzity (Kejř 1995: 21-32) lze vidět i jiné než mocensky orientované pohnutky. 


\section{Filozofie a medicína v rozhovoru s právem}

Abychom však mohli smysluplně vyložit způsob, jakým Pěčka ve svém díle začleňuje právo do dialogu s ostatními obory, filozofií a medicínou, musíme alespoň stručně nastínit, čím argumentují a čeho se dovolávají orátorovi bratři usilující o vítězství v učené při, skrze jaké kategorie definují vlastní odbornost a jak komunikují s ostatními dvěma „konkurenty“. Orátor se totiž dostává ke slovu až jako poslední, takže jeho reakce na předchozí dvě promluvy je pouze logickým vyústěním celé, v promluvách vygradované debaty, pomineme-li závěrečný nález, který je ovšem v rukou přizvaných soudců.

Jako první se na soudce a ostatní dva bratry se svou obhajobou a řečí obrací ten, kdo je nejstarší, totiž bratr filozof vychvalující filozofii, „kterak by ona všeho všudy umění, jak nebeského, tak i zemského, viditedlného i neviditedlného, vnitřního i zevnitřního př́íčinou přední a původem byla“ (Pěčka 1609: C3b). Způsob, jakým své umění vymezuje, zůstává tradiční, zakotvený ve vědomí, že filozofie je matkou všech věd, nejstarším oborem systematicko-kritického myšlení. Filozofův duch proniká veškeré lidské poznání až k vysokému horizontu nebeskému a k hlubokým propastem země. Postihuje metafyzický pramen a smysl všech jevů. Zpytuje povahu, náklonosti i rozdílnosti časů, míst, osob i všech věcí. Díky své vnitřní bohatosti je filozofie prospěšná všem, každého přivádí k tomu, aby sám sebe poznával a měnil a přitom se zároveň staral o svět kolem sebe a svou obec (Pěčka 1609: C6a).

Právě tento univerzálně celistvý a na podstatu soustředěný záběr filozofie je tím, na čem staví bratr filozof svi̊j nárok na čtvrtý díl dědictví po otci. Nepřekvapí nás proto, že to bude bratr filozof, kdo se nejzřetelněji vysloví i k námi hledanému pomyslnému řádu hierarchie a vzájemnosti mezi vědami. Stejně jako je bratr filozof mezi svými bratry nejstarší, je rovněž filozofie nejstarší z věd. Obor jejího zájmu se současně rozevírá nejšířeji i nejhlouběji. Ačkoli se medicína, kromě praktického léčení, hledání a pojmenování nemocí, zabývá také př́rodní filozofií, a v tomto ohledu mají k sobě bratr doktor a filozof velmi blízko, existují podle filozofa témata, která medicína nepojednává a která z filozofie pouze přebírá jako svůj předpoklad, např. otázky metafyzické. Proto je medicína na rozdíl od filozofie vědou částečnou, na filozofii metodicky (dialektika) i obsahově (fyzika) závislou. Pro právo a bratra orátora aneb prokurátora platí totéž, avšak v míře ještě o řád vyšší (Pěčka 1609: C4a, b). Z filozofova hlediska se jeví umění orátorovo jen jako úzký a uzavřený prostor, vymezený problémy lidského jednání, pokoje, války a spravedlnosti. Podobně jako v př́ípadě medicíny, i právo a s ním spojené řečnictví přitom navíc za mnohé vděčí právě filozofii. Řečník, který má být nejprve mužem ctnostným a teprve potom výmluvným, je závislý na filozofovi, k jehož kompetenci přirozeně náleží rovněž pojednání o ctnostech. Stručně řečeno, filozofưv nárok na nejpřednější místo mezi bratry a jejich vědami se opírá o klasické tvrzení, že filozofie je matkou všech věd a ostatní jsou na ní bytostně závislé (Pěčka 1609: D7a).

Po filozofovi se ujímá slova prostřední bratr lékař²3, aby obhájil „,vznešené, slavné a božské umění lékařské, lidskému pokolení z nebe dolů seslané pro zachování života,

23 Faktografický přehled dějin lékařství u Porter (2013), ovšem bez přihlédnutí k českým poměrům. Dějinám domácího středověkého lékařství a jeho pramenům se věnuje Milada Ř́íhová (2002), tam i další literatura. V mnohém její postřehy odpovídají tomu, o čem níže píše Pěčka, at' už jde o otázky profesní etiky, zařazení medicíny do systému věd či postavení lékaře ve společnosti. 
poznání našeho přirození v sobě zdržujícího“ (Pěčka 1609: J4a). Lékař zde naznačuje, o co usiluje lékařské umění - o zachování života a poznání lidské přirozenosti. Co si však lékař spojuje s pojmem zdraví, jestliže je hodnotí jako ten pravý důvod, pro který je právě lékařství oborem nejprospěšnějším vlasti? Jeho pohled rozhodně není tak omezený, aby jím mínil pouhé bezvadné fungování organismu. Zdraví pro lékaře představuje ve shodě s renesanční prírodní filozofií především prostředí a substrát, od nějž se odvíjí každá další činnost člověka. Zdraví je v nejlepším slova smyslu prostředkem, který umožňuje smysluplně žít. V době, kdy Pěčka sepisuje Akci a rozepře, znamená zdraví zároveň vztah ke hvězdám, živlům, obci, celému světu, všepronikajícímu světovému řádu. Tak i bratr lékař, sám sebe označující za bratra mezi filozofem a prokurátorem prostředního, vidí svůj úkol ve zprostředkovávání zdraví jakožto nutného předpokladu a prostředku žití, čímž zároveň slouží své vlasti, protože zdraví nesouvisí jenom s bytím člověka, ale i s jeho souladným vztahem ke světu. Ke zdraví lékař přistupuje celostně (Pěčka 1609: J4b, K7a). Je proto nucen zajímat se o vše, co může optikou celostního přístupu medicíny člověku prospívat. Není tedy divu, že lékařské umění naslouchá jiným spř́zněným vědám, zvláště etice a filozofii a v jejím rámci fyzice a př́rodozpytu (Pěčka 1609: C4a, b). Určujícím kritériem, podle něhož lékař zvažuje, které znalosti pramenící z filozofie, astrologie, dialektiky nebo fyziky by se mu mohly v budoucnu hodit při léčení pacientů, je praktická použitelnost věd soustředěných v lékařském umění.

Ačkoliv ve své obhajobě lékař cítí potřebu zdůraznit zejména praktickou stránku lékařského umění, je si zároveň velmi dobře vědom důležitosti teorie, filozofického nazírání světa a místa člověka v něm pro lékařskou praxi. To, co lékaře sbližuje s filozofem, je snaha porozumět lidské přirozenosti, $\mathrm{k}$ čemuž oba nutně potřebují proniknout do základů tehdejšího vědění, vyučovaného na artistické a lékařské fakultě. Kromě vědomí nutnosti překračovat hranice vlastní odbornosti směrem k filozofii, uvažuje lékař také o svém vztahu k právu. Ten se odráží v normativním a preskriptivním rozměru lékařství, kdy lékař z titulu své učenosti a zkušenosti přikazuje lidem, jak mají pečovat o své zdraví. Lékař se tímto způsobem přibližuje zákonodárci nebo vladaři, jimž znalost obce a jejích obyvatel umožňuje zavést dobrou správu, udržovat ji v rovnováze. To, co dále spojuje lékaře s orátorem, je kritika čisté, na životě nezúčastněné teorie a společný důraz na praktickou rovinu věd a umění. Protože pak každá praxe spočívá v eticky reflektovatelném lidském jednání, medicína i právo se ve svém zájmu o adekvátní uplatnění svých odborností setkávají také s etickou filozofií, z níž přeci veškerá etická zkoumání a zpytování vychází.

Filozofie i medicína jsou v promluvách obou starších bratrů představeny jako plnohodnotné vědy. $Z$ hlediska jejich vnitřní oborové konstituce tomu odpovídá vždy jedinečný způsob, jakým přitakávají na jedné straně životu s jeho praktickými potřebami a problémy, na druhé straně antické i křest’anské tradici teoretického poznání, jehož institucionálním výrazem jsou v období raného novověku hojně zakládané akademie a reformované univerzity vytváŕející platformu $\mathrm{k}$ novému intenzivnímu promýšlení samotných základů jednotlivých odborností. Z vnějšího hlediska pak obě disciplíny představuje Pěčka jako skutečnou součást jediného prostoru legitimního poznání. Medicína ani filozofie nejsou podle Pěčkova podání bez vztahů $\mathrm{k}$ sobě navzájem či $\mathrm{k}$ ostatním tradičním disciplínám, ba právě naopak - existence těchto vztahů spoluodůvodňuje jejich pravou vědeckost. Proto se bratr lékař i bratr filozof ve svých obhajobách tolikrát obracejí i na právo. 
Nesmí nás mást, že vztah k právu je reflektován nejčastěji v kritikách adresovaných prokurátorovi ${ }^{24}$, jimiž se bratři snaží vyrovnat s výtkami dopadajícími na jejich hlavu. Právě v nich si filozof i lékař uvědomují své přednosti, nutí je však současně k zamyšlení nad vlastními slabostmi. Pranýřuje-li filozof prokurátora za jeho etické prohřešky, naznačuje tím styčné body mezi právem a filozofií, tedy morální filozofii a etiku ctností. Snaží-li se od sebe důsledně odlišit orátora od prokurátora, upozorňuje tím bezděky na společné kořeny vyrůstající z řečnického umění. Stejně tak lékař, zdůrazňující primárně důležitost praxe, kritizuje-li neučenost a neschopnost právních praktiků, ví, že i medicínu stíhají stejné neduhy a že lékaře s prokurátory pojí nutnost neustálé reflexe etické relevance jejich praktického jednání. Vždyt' právě na dodržování vnitřních etických norem vlastních oběma těmto vědám je bytostně závislá přesvědčivost a legitimita normativních nároků, které tato umění kladou na své vnější adresáty, at' už se jedná o pacienty či adresáty právních předpisů. Mnohé tedy, co spojuje právo s filozofií či právo s medicínou, zároveň odůvodňuje společenskou prospěšnost zmíněných věd. S jakým specifickým posláním pak před ostatní předstupuje poslední řečník - nejmladší bratr orátor aneb prokurátor, aby zvítězil v naší učené při?

\section{Právo v rozhovoru s filozofií a medicínou}

Dříve než se pustíme do rozboru jeho výpovědi, musíme si položit několik otázek týkajících se odbornosti, na jejíž obranu bratr orátor aneb prokurátor před soudci a oběma svými bratry vystupuje. Co se zde touto odborností míní? Jak je zjevné ze způsobu, kterým Pěčka nejmladšího $\mathrm{z}$ bratrů tituluje, jedná se $\mathrm{v}$ jeho případě o rétoriku $\mathrm{v}$ těsném spojení $\mathrm{s}$ právem, které ostatně bratr orátor na různých místech Akcí a rozepře zmiňuje. Jak ale tomuto spojení hlouběji rozumět? Jaké bylo právo Pěčkovy doby, že tak samozřejmě souviselo s teoretickou i praktickou stránkou rétoriky? A co tato souvislost znamenala pro vztahy práva k ostatním oborům?

V celé Akcí a rozepre je právo představováno hned v několika různých významových rovinách. Protože se sám spor tři bratří odehrává před soudci, první rovina př́mo bezprostředně souvisí s právním fórem, na němž je možné ,podat se ku právu“, „obeslat někoho před právo“, tj. vystoupit s požadavkem naplnění spravedlnosti na soudě (Pěčka 1609: N3b). Další významy, které se v rámci právního fóra uplatňují, se pojí bud' s právním nárokem, nebo př́mo s právem (Pěčka 1609: Q2b) jako, moderně řečeno, souborem právních předpisů (Pěčka 1609: N4a, b). Tyto přitom nemusely mít v období raného novověku nutně normativní povahu a míra jejich závaznosti nemusela být dána „státní vynutitelností“, ale mohla být vyvozována z titulu jiné mimoprávní autority, např. obyčeje či morálky. Složitost právního rádu Pěčkovy doby byla navíc umocněna dosud stále existujícím právním partikularismem, který určoval obsah i podobu tehdejších pramenů práva. Sám Pěčka explicitně uvádí právo městské nebo zrrízení zemské, které lze v této době považovat, vyjma učených práv, v českých zemích za nejdůležitější.

24 Kritické hlasy na adresu prokurátorů v českých zemích zaznívaly mnohem dříve, než byla vydána Akci a rozepre (Štachová 2014: 419-423). 
Tyto základní, spíše praktické významové roviny, které se pojí s bezprostředním právním životem i s vlastním syžetem našeho spisu, se Pěčka pokouší v rámci orátorovy promluvy prohloubit vzhledem k projednávané otázce o smyslu práva ve společnosti. Na jednom místě se dokonce sám pokouší o definici toho, co je podstatou práva. „Práva zajisté jsou obce svazkové, základové svobody, života lidského kratochvíle a jako nějaké pevné zdi a outočiště vrchnosti proti lidu zlému a neposlušnému“ (Pěčka 1609: V8b). Pěčka toto vymezení nevolí náhodou, vždyt’ za nejvyšší právo považuje obecné dobré (Pěčka 1609: O4a) ${ }^{25}$, tj. prospěch obce, a o ten ve sporu o čtvrtý díl dědictví běží především. Protože tam, kde právo chybí, společnost trpí chaosem či tyranií. Pěčka zde zdůrazňuje typicky novověké chápání práva související s ideálem jasného, pevného a určitého rozumového řádu, jak se prosadil později během a po třicetileté válce a za osvícenství (Hattenhauer 1998: 359).

Právní řád zaručující obci prospěch a dobro ale nikdy neexistuje jako předem hotové abstraktum. Bez fenoménu právního vědomí, bez učené právní vědy a bez právní kultury, která obě předchozí kategorie v sobě spojuje $\mathrm{e}^{26}$, není jeho smysluplná existence ve společnosti myslitelná. I o tomto méně nápadném rozměru práva podává Pěčka v Akcí a rozepře svědectví. Sám je přitom přirozeně ovlivněn dobovým stavem právní kultury v českých zemích v éře předbělohorské. Máme-li zhodnotit její úroveň, musíme mít na zřeteli, že z původních čtyř fakult Karlovy univerzity funguje za Pěčkova života pouze fakulta artistická. Chod ostatních fakult je obnoven teprve v souvislosti s činností jezuitů po bitvě na Bílé hoře. ${ }^{27}$ Uzavření vysokého učení uchazečům o studium práv a medicíny na dlouhých 200 let má samozřejmě negativní dopad i na úroveň právní kultury. Jak dokazuje Akcí a rozepře a mnohá jiná díla, právnický stav, ani právo samo však v tomto období ze společnosti nevymizely. Právnické vzdělání zajišt'uje sice spíše výjimečně studium práv na některé ze zahraničních univerzit, určující silou formující př́slušníky právnických profesí je však dozajista praxe, budující na znalostech platného práva $\mathrm{v}$ podobě tištěných zemských zrrízení či kodexů městského práva namnoze již ovlivněných římským právem, četbou antických autorů i elegantním stylem vyjadřování.

Pronikání římského práva do českého prostředí v předbělohorském období ovšem nelze jednoduše ztotožnit s právním humanismem ve smyslu nového př́istupu ke zpracování římského práva tak, jak se prosadil zejména ve Francii 16. století (Seltenreich 1996: 230-233). Nanejvýše můžeme hovořit o jednotlivcích, jako byli Jan Kocín z Kocinétu či Jan Matyáš ze Sudet, kteří svou tvorbou po létech strávených v zahraničí přenáší ozvuky právního humanismu do domácího prostredí (Klabouch 1962: 295-298). Větší vliv než škola právního humanismu si v českých zemích získává skupina právníků-humanistů, jejichž význam tkví ve zprostředkování rímskoprávních znalostí domácímu učenému publiku (Klabouch 1962: 292-293) a ve zvědečtění právního života (Urfus 1994: 8). Položit základy moderní jurisprudence by

25 k jeho interpretaci v zemských zř́zeních 16. století srov. Adamová (2001).

26 Vymezení pojmu právní kultura a její proměny ve středověku a raném novověku podávají Kejř (1996) a Malý (2001).

27 K dějinám Karlovy univerzity a jejích jednotlivých fakult do Bílé hory srov. Čornejová (1995), po roce 1622 srov. Beránek (1996). 
však bylo stěží možné bez rozsáhlé sítě partikulárních škol i pražské univerzity ${ }^{28}$, které institucionálně zajišt’ují humanistické vzdělání a nabízí portfolio oborů přispívajících k praktické výbavě budoucích právníků. Čelné postavení mezi nimi je vyhrazeno rétorice, která propojuje právo a jeho kulturu s ostatními sférami lidského ducha, takže lze tvrdit, že specifickým rysem právní kultury v době humanistické zůstává, kromě výše uvedeného, její otevřenost k ostatním vědám a uměním. Skrze řečnictví se právo profiluje, mluví, zapojuje se do dialogu s ostatními vědami. Poukazovat na slovo zaznívající uvnitř a zevnitř práva proto znamená akcentovat jeho řečnickou a literární rovinu, jeho rétorické dědictví.

Jestliže se tedy bratr orátor dostává ve sporu tří bratří ke slovu, spolu s ním se ke slovu dostává také tehdejší právo chápané $\mathrm{v}$ těsné spojitosti s rétorikou. V čem pak spočívá jádro obhajoby jeho umění? Rétorika má samozřejmě mnoho styčných bodů s právem a bylo by lze proto uvažovat o různých hodnotách, které spojení práva a rétoriky společnosti přináśí. Bratr orátor také mnohé z nich zmiňuje, ale jednoznačně platí, že na prvním místě zdůrazňuje rád a právo tvořící výmluvnost. Takový důraz na výmluvnost souvisí s jejím velmi bohatým chápáním. Výmluvnost totiž podle Pěčkova narativního podání pochází přímo od Boha, a tak její oslava, kterou bratr orátor ve své řeči podává, legitimuje poslání a místo práva a řečnictví v kosmickém a lidském řádu. ${ }^{29}$

Jak trefně poznamenává Pěčka, člověk je člověkem právě díky daru řeči. Výmluvností se, vyjma duše, odlišuje od nerozumných „hovad“ (moderně řečeno, výmluvnost tvoří tzv. antropologickou diferenci). Darovaná výmluvnost uschopňuje člověka k mocné, významuplné řeči a tím jej zároveň uvádí do sociálního bytí, do eticky relevantního života s druhými. Avšak výmluvnost, která se uplatňuje vzhledem $\mathrm{k}$ druhým lidem, musí odpovídat na nárok opravdovosti. Proto by měl mít každý dobrý řečník na paměti vztah k pravdě, která člověka přesahuje, a vztah k druhým lidem, na které se se svou řečí obrací, chce-li skutečně rádně vykonávat svou službu klientům. Důrazem položeným na etiku advokátského stavu orátor v Akcí a rozepře znovu oživuje známou Quintiliánovu tezi, podle níž lze za pravého řečníka považovat pouze toho, kdo je v prvé řadě ctnostný, potom teprve výmluvný (Quintilianus 1985: 546). Je zásluhou Pěčky, že tento etický princip vztahuje také na prokurátory, nikoliv pouze na orátory ve smyslu veřejně činných osob.

Zdravá sít' sociálních vazeb mezi lidmi nevzniká tedy jen prostou výřečností, ale výmluvností, která je vnitřně pravdivá a mocná. Proto orátor výmluvnost představuje jako společnost tvořící a zachovávající sílu, která obci prospívá v míru i válce. Je to výmluvnost, která založí obec, povolá lidi do měst z lesů a pustin, ustaví žádoucí rád prostřednictvím práva a zákonů a určí vrchnost, které mají být všichni poslušni (Pěčka 1609: V2a). Všechny přednosti, které náleží výmluvnosti, patří samozřejmě také orátorovi aneb prokurátorovi. Svou převahu nad ostatními bratry orátor demonstruje na imaginárním př́kladu z minulosti,

28 Systém předbělohorského vzdělávání s důrazem na vazbu pražské univerzity k rozsáhlé síti městských škol podrobně líčí Pešek (1993: zejm. 30-58, 1995: 219-226).

29 Podobný př́iběh o třech sestrách, sochařství, maliřství a architektuře, jejichž otcem je Disegno a matkou Invenzione, zná kunsthistorie (Kroupa 1996: 60). Př́značné je nejen to, že sestry symbolizují tři obory, ale že spojením s ideálem mají být podle představ Giorgio Vasariho povýšeny mezi „vyšší“ umění. Za zprostředkování této informace děkuji kolegovi Ondřeji Horákovi. 
v němž se angažuje ve prospěch záchrany vlasti. Př́iběh, v němž orátor výmluvností triumfuje nad lékařem a filozofem, kteří jsou v dané chvíli bezradní, má jen více podtrhnout fakt, že orátor je v čase války pro obec nepostradatelný. Zatímco doktor má místo jen u nemocných a filozof pouze na akademické půdě, orátor se uplatní všude, kde existuje nějaké spolubytí lidí, tedy nejen na vysoké škole, ale i na radnici, na soudě nebo dokonce v kostele, kde uděluje pronikavé rady, straní spravedlnosti, nabádá k následování Krista (Pěčka 1609: V2b).

Ovládnout řečnické umění, jímž orátor nadchne své posluchače, vyžaduje ovšem kromě vytrvalého pěstování ctností i nemalé úsilí v dalších oblastech. Pro budoucího řečníka jsou důležitá pravidelná cvičení i určité vrozené vlohy. Nezanedbatelný pro dosažení vrcholu řečnického umění je věk. V praxi však nejde pouze o znalost a volbu vhodného řečnického stylu, ovládání gest a mimiky, techniku přednesu a koordinaci obsahu řeči s její formou, ale také, kromě poctivosti a čestného jednání, o učenost, znalost práva a touhu dosáhnout spravedlnosti (Pěčka 1609: V8a). Ne náhodou jsou orátoři vysoce ceněni a váženi proto, že dokonale rozumí správě obce, zákonům, které ji ovládají, i potřebám jejích obyvatel, jimž mají radit před soudem nebo při jiných prŕíležitostech. Neučenost proto orátor ostře kritizuje a zvlášt’ se přitom dotýká českých poměrů (Pěčka 1609: V7a, b).

Božský původ výmluvnosti, práce pro obec a učenost či znalost zákonů podle bratra orátora jistě odůvodňují jeho nárok na vítězství v našem sporu, a tedy i na čtvrtý díl dědictví. Tento názor však přirozeně nesdílí ani filozof (Pěčka 1609: F8a-H2b), ani lékař (Pěčka 1609: N1b-N8b). Jak jsme viděli výše, jejich vlastní odbornosti se také mohou pyšnit zvláštní péčí o dobro a prospěšnost obce. Navíc samo řečnictví a právo v jejich očích v mnohých ze svých úkolů selhávají. Bratři naříkají nad neuspokojivým stavem řečníků, kteří sice znají práva, ale sami je nedodržují a ohýbají právní rád tak, jak je jim libo. Výřečnosti, která je tak mocným darem, advokáti zneužívají ke svému vlastnímu prospěchu či k obhajobě zlého.

Taková eticky laděná kritika pochopitelně dominuje vzájemnému vymezování jednotlivých oborů zastoupených protagonisty Pěčkova Akcí a rozepře, vždyt’ celý spor je vystavěn především konfrontačně kolem hledání oboru, který je vlasti nejprospěšnější. V našem sporu může proto zvítězit jen jediný. Avšak nutnost vést společně rozhovor a vzájemně se konfrontovat odhaluje zároveň mezi rodnými bratry méně patrnou rovinu komunikace, která se zakládá na vzájemném zrcadlení oborové terminologie a dalších analogiích. Jen skutečná výmluvnost dokáže tyto analogie vystavět a smysluplně používat. Tak při bližším pohledu zjišt'ujeme, že i lékař a filozof určitým způsobem výmluvně využívají právních kategorií ve vztahu ke svým odbornostem a uvažují o nich v kontextu vlastního odborného zaměření. Dobře to dokumentuje lékařské umění a jeho normativní rozměr, kterého si je vědom bratr lékař. Ve své obhajobě se před soudci vychloubá, že na rozdíl od svých bratři může cokoliv beztrestně přikazovat nebo předepisovat dokonce samotnému císaři nebo papeži. Lékař tedy stejně jako zákonodárce vynáší předpisy, které stanovují př́ípustné meze chování, kromě toho účinně zasahuje svými léčebnými metodami do života jednotlivce, jemuž navrací původní zdraví. Analogicky se tak poslání a úkoly lékaře dají vztáhnout na vladaře, který spravuje obec (lékař pečuje o lidské tělo a ducha), vydává pro ni zákony (lékař navrhuje preventivní opatření) a zasahuje do ní proto, aby byla zdravá (lékař předepisuje léky a jiné prostředky k dosažení a uchování zdraví). 
Filozof rovněž využívá přirovnání pocházející z práva. „Aniž jest co jiného filozofia, jedině jakýsi zákon a právo života...“ (Pěčka 1609: E7b). Filozof zde naráží na podstatný rys práva, které svým působením plní základní a zakládající úlohu v životě obce, protože je povoláno udržovat její řád. Ne náhodou se filozofovi hodí na uvedeném místě své obhajoby tímto odkazem podtrhnout také „,normativnost“ filozofie, která podobně jako právo říká, jaké je základní místo člověka ve společnosti, v níž by měl důstojně a řádně nažívat s ostatními.

Jak je tedy zjevné z námi analyzovaného spisu, filozofie i lékařství pracují při pojednávání svých témat s analogiemi vztaženými k právu (Burke 2007: 234-235). Smysluplnost a hojnost takovýchto prolnutí bude ale vždy nakonec záležet na tom, jak si řečníci poradí s úkolem výmluvně a sdělitelně formulovat vlastní pojmy a skutečnosti tak, aby je mohli nabídnout ostatním vědám jako inspiraci a výchozí bod k úvahám nad problémy patř́íími $\mathrm{k}$ jejich oboru. V Pěčkově době tento nesnadný literární proces umožňovala obecně sdílená humanistická intelektuální komunikace. Ačkoliv soudci při svém posuzování sporu tento směr úvah primárně nesledují, rozhodují-li o tom, který z bratří je vlasti nejprospěšnější, je úspěch či neúspěch práva při naplňování uvedeného úkolu v takovémto rozhodování vždy implicitně obsažen.

\section{Závěrečný nález a modely interdisciplinarity}

Spor a disputace tří rodných bratří se uzavírá vynesením nálezu (Pěčka 1609: W6a-X2b). Soudcové nejprve přiznávají jistou užitečnost a prospěšnost všem bratrům a jejich uměním, filozofii, právu i lékařství. Na základě jakého kritéria se však rozhodnou pro jednoho z nich, aby určili, kdo je obci nejprospěšnější?

Tímto kritériem se stanou kategorie univerzálního a singulárního, obecného a jednotlivého, a jejich projevy v tom kterém umění. Podle mínění soudců jenom umění právní čili řečnické vždy zohledňuje jedinečnost situace, v níž se uplatňuje, a zároveň obecnou platnost a pravdivost, díky níž není prázdné, ale skutečně účinné. Tajemství orátorova úspěchu tkví v pravdivé výmluvnosti, která zprostřredkovává jedinečné v univerzálním a univerzální v jedinečném. Řečníkovo slovo zaznívá do konkrétních problémů a sporů. Aby v nich ale mohlo předznamenat mír, musí být samo vyjádřením principů spravedlnosti a ztělesněním míru na základní rovině bytí. Naopak filozof podle soudců zkoumá jen tuto rovinu idejí a principů a zůstává v ní uzavřen, zabývá se věcmi věčnými a obecnými a neuplatňuje je v praxi. Lékaře zase zajímají pouze jednotlivé konkrétní otázky a problémy, nebot' léćí jednotlivce, nikoli celou obec. $\mathrm{V}$ tomto smyslu soudcové uzavírají při nepř́iliš překvapivým nálezem, v níž díky své výmluvnosti vítězí bratr orátor aneb prokurátor.

Svým konečným rozhodnutím soudcové ustavují model vztahů mezi filozofií, právem a medicínou, založený na rozlišování obecného a jednotlivého. V tomto modelu, jak je př́itomen v Pěčkově Akci a rozepre, hraje ústřední roli právo chápané v souvislosti s řečnictvím. Pěčka jeho užitím navazuje na dlouhou, především filozofickou, tradici uvažování o možnostech poznání a vědy. Už Aristoteles si všímá, že o jedinečném není teoretické vědy (epistémé). Tuto základní tezi hojně komentují i scholastikové a její význam se projevuje i v raném novověku postrenesančním důrazem na hledání univerzální racionální filozofie (Descartes). Na druhou stranu byla tato teze právě v renesanci korigována důrazem 
na empirické popisné poznání konkrétní jedinečné skutečnosti. V Pěčkově Akcí a rozepře je tento filozofický problém vztahu obecného a konkrétního posunut směrem k nesamozřejmému a tehdy často diskutovanému poměru mezi konkrétní praxí (ars) a obecnou teorií (scientia) (Burke 2007: 105), protože ve sporu tří bratří neběží o čistě teoretické poznání (epistémé), ale především o poznání, které je prospěšné vlasti. Takové praktické poznání se však $\mathrm{k}$ něčemu konkrétnímu vztahuje vždy, proto díky tomuto přenesení důrazu z teorie k praxi mohl v modelu vztahů mezi filozofií, právem a medicínou, založeném na rozlišování obecného a jednotlivého, zaujmout ústřední postavení právě bratr orátor aneb prokurátor.

Podle tohoto modelu vynesli soudcové své poslední slovo a svůj nález, ale náš pokus o identifikaci raně novověkých modelů interdisciplinarity v Pěčkově Akcí a rozepre zde skončit nemůže. $V$ analýze jednotlivých promluv, kterou jsme prováděli výše, jsme se totiž setkali s dalšími modely interdisciplinarity zohledňujícími i jiné skutečnosti, a proto nejsme při našem závěrečném hodnocení místa práva mezi ostatními vědními disciplínami počínajícího novověku odkázáni pouze na toto závěrečné rozhodnutí soudců.

Byl to především model, který ve své obhajobě popisuje bratr filozof. Podle něj je filozofie oborem nejstarším a nejobsáhlejším, zahrnujícím v sobě všechno poznání. Medicínu z filozofie zajímá jen část, která se zabývá otázkami přirozenosti věcí. Právo je pak vůbec tím nejomezenějším oborem, nebot' je samo založeno na stanovování mezí. Je možné uvést v soulad tento tradiční a v dobové literature často se projevující filozofův model (philosophia jako mater scientiarum) s modelem, dle něhož soudcové rozhodli při? Zdá se nám, že konstatování o oborové omezenosti práva je poměrně výstižné. Avšak tato oborová omezenost nutí právníka či orátora $\mathrm{k}$ tomu, aby namísto spekulativních rozletů věnoval pozornost službě jednotlivému a jedinečnému. Díky jeho rétorické výmluvnosti se zmíněná pozornost stává prostředkem sdělování pravd, které mají mít obecnou platnost. Ovšemže bude vždy filozof ve spekulativním nahlížení těchto pravd obratnější a na rozdíl od orátora je postihne v jejich pravé šíri i hloubce, přesto zůstává právě rétorovým úkolem se této hloubky dotknout a od ní se odrazit $\mathrm{k}$ hladině setkání $\mathrm{s}$ jednotlivým, praktickým, částečným a zde být užitečný ve věci spravedlnosti a míru. Tradiční mateřská úloha filozofie tak v žádném případě nepopírá zvláštní význam práva a řečnictví, jak je ve vzájemné souvislosti popisuje Pěčka. Pro každý z vědních oborů i jejich vzájemnou komunikaci je naopak důležité, že i tento model zůstává v období raného novověku stále smysluplným.

Bratr fillozof v Akci a rozepre načrtává ještě jiné vymezení vztahů mezi filozofií, právem a medicínou, tentokrát založené na vztazích významové následnosti. „[F]ilozof bývá moudrým před skutkem aneb oučinkem, lékař v oučinku, ale prokurátor teprve po účinku“ (Pěčka 1609: G2a). Filozof rozjímá a spekuluje nezávisle na tom, zda se předmět jeho myšlení uskutečňuje, nebo ne. Lékař se naopak uplatňuje vždy s ohledem $\mathrm{k}$ prrítomnému, probíhajícímu dění. Bud' udržuje zdraví, které je podmínkou jakéhokoli dalšího konání, nebo léčí nemoc. Prokurátor potom přichází vždy až po dokonání př́slušného děje, jehož interpretaci obhajuje či posuzuje. V tomto modelu se všechny tři odbornosti doplňují a řád mezi nimi nevyzdvihuje jednu nad druhou.

V podobném duchu pojednává vztah mezi vědami i bratr orátor, když se zamýšlí nad tím, zda má celý spor o čtvrtý díl dědictví po otci smysl, zda není jen projevem nepokory všech tř́i bratř́i. 
Lidé pak smrtedlní, souce mnohem nižší nežli bohové, majíc příklad na těchto třech bratřích, nechtějí na svém přestávati, než vždycky hledí jeden druhého o jeho vlastní připraviti, chtíce všecken svět válkami, ohněm a mečem pohubiti, nebe, moře a zemi vopak drtem obrátiti a naposledy samého Boha, jako kteří gigantové z stolice jeho zsaditi a na ní se sami posaditi. (Pěčka 1609: Q5b)

Zde bratr orátor naznačuje nutnost existence pevného řádu mezi sférami zájmu jednotlivých oborů. Nepřekvapí, že s takovýmto pojetím přichází právě orátor, vždyt' jak jsme již viděli, je to právo, které spočívá ve vymezování rádu. Tento pomyslný řád určující tzv. kompetenční pole mezi vědami je dobře znám z dnešního moderního pojetí interdisciplinarity, ve kterém se při jakékoli badatelské spolupráci či konfrontaci oprávněně zdůrazňuje vzájemná nutnost respektovat své odborné kompetence.

Výsledný obraz je tedy podstatně pestřejší a aktuálnější, než by se z výroku soudců mohlo na první pohled zdát. $\mathrm{V}$ průběhu disputací bratří jsme viděli, že si každý z př́íslušných oborů nárokuje obecnou platnost a obhajuje své místo mezi ostatními vědami, které je současně význačné i otevřené $\mathrm{k}$ dialogu s dalšími obory. Filozofie v Pěčkově díle ve shodě s převažující evropskou intelektuální tradicí tvoří základ všeho vědění. Vše, co člověka tvoří, obklopuje i přssahuje, zkoumá a promýšlí. Lékařství, chápané u Pěčky v celostním renesančním duchu, svou péčí o zdraví, které se týká všech lidí bez výjimky, je tím, co člověku umožňuje rozvíjet všechny jeho činnosti v různých směrech lidského života. Právo spojené s humanistickou literární vzdělaností a řečnictvím díky ctnostné výmluvnosti zase všechno správně vyslovuje a přivádí $\mathrm{k}$ porozumění a spravedlnosti. Prvek univerzálnosti je tedy zastoupen u každé $\mathrm{z}$ těchto věd. Jeho př́tomnost může mít ale dvojí význam. Bud' vstř́ícně otevírá př́slušný obor oborům ostatním, nebo se stává důvodem pro obhajobu jeho dominance a převahy nad ostatními.

\section{Závěr: o právu, které se nebojí rozhovoru}

Sám Pěčka svi̊j dialog pojímá v dobovém duchu konfrontačně a apologeticky, proto v $A k c i$ a rozepře převažuje snaha obhájit svůj obor a zpochybnit obory ostatní. Námi hledaná bazální interdisciplinární komunikace zde probíhá primárně v rovině vzájemných kritik, v celém díle převažuje polemický tón odpovídající zvolenému syžetu. Jak jsme však viděli, podrobnější analýza ukázala i náznaky jiných, kooperativnějších, jednotu zdůrazňujících, bratrských modelů vzájemnosti věd.

Pěčkova Akci a rozepře samozřejmě nepředstavuje důkladný systematicko-teoretický traktát, který by do raně novověké debaty o novém založení věd a jejich uspořádání mohl výrazněji zasáhnout. Jeho smysl dnes spočívá hlavně v tom, že svědčí o možnosti dobové smysluplné, vzájemné, bazální interdisciplinární komunikace napříč tradičními disciplínami, o jejích podmínkách a o místě práva v ní. Stabilizované humanistické komunikační pole a široce sdílená učenecká kultura takovou výměnu názorů, podnětů a představ umožňovaly. Pěčkův spis proto ještě nenese rysy novověkého oddělení okruhu humanitních a okruhu př́rodních věd ani novověké oborové fragmentarizace či striktní pojmové specializace. Náleží spíše ke středověkému a renesančnímu pojetí vědy, jak jsme je v náčrtu dějin interdisciplinarity charakterizovali výše. Ostatně i sami účastníci sporu vystupují jako př́buzní, dokonce 
rodní bratři, které kojila táž matka Moudrost. Základem řádu mezi nimi je jejich věk. Bratr filozof pak jako nejstarší odpovídá filozofii jako nejstarší mezi vědami.

V Pěčkově díle je toto původní bratrství narušeno a vystaveno sporu, v němž vítězí bratr orátor aneb prokurátor díky své pověstné výmluvnosti. K umění právnímu a právu jako takovému bytostně patři jeho řečnická či literární rovina. ${ }^{30}$ Slovo, které zaznívá uvnitř práva (při disputacích, vyučování, v právních knihách, zákonech, soudních rozhodnutích atd.), je současně vyjadřováno navenek, a tím slouží vlasti. V tom podle Pěčky a soudců spočívá pravá užitečnost i vznešenost práva, že se nebojí promluvit v interdisciplinárním rozhovoru či otevř́ít diskusi, která oslovuje intelektuální svět i celou společnost. Přitom konečně formát sporu, jejž dle určité procedury dokazování rozhodují soudci a který je strukturován podle obhajob přímluvců a kritických napadání odpůrců, není náhodný. Vychází z antické právní i dialogické tradice a projevil se rovněž při scholastických disputacích na univerzitách (Burke 2007: 51). Coby literární útvar má tedy svůj vzor právě v právu! V tomto smyslu lze celé Pěčkovo dílo Akci a rozepre považovat za takové vyjití slova z nitra práva k ostatním vědám a uměním.

\section{Prameny}

Beroaldus, Philippus. 1497. Philippi Beroaldi opusculum eruditum quo continetur Declamatio Philosophi, Medici et Oratoris de excelle [n] tia discepta[ntiu[m] et libellus de optimo status [et] principe. Bononiae: Benedictus Hectoris [Faelli].

Kittlitz, Karl von. 1600. Orationes XI. de comparatione medici, philosophi et oratoris: exercitii gratia Argentinensi in academia scriptae ac recitatae Anno M. DC. Ab Domino Carolo L. barone de Kittlitz, in Malnitz et Eisenberg et aliis nobilibvs adolescentibvs, eloqventiae stvdiosis. Argentinae: Typis Iosiae Rihelii, per Andream Rietschium.

Pěčka z Radostic, Michal. 1609. Akcy a Rozepře Mezy Filozoffem, w Lékařstwij Doktorem, a Orátorem aneb Prokurátorem Třmi wl'astnjmi Bratry, Kterýby z nich Obcy a Wlasti swé neypl'atněgssý a neyvžitečněgssý býti a tak wedlé Kssafftu Otcowského dwau djlu Statku po něm dostati měl’. Yak Včeným a Maudrým tak y Prokurátorům weymluwným a wssechněm Lidem Obcy a Wlasti swé slaužjcým mil’á, prospěssná, a vžitečná. Wydaná od Michal'a Piečky Smržického z Radostic... Wytisstěno w Starém Městě Pražském: v Pawla Sessya.

\section{Literatura}

Adamová, Karolina. 2001. „Obecné dobré a idea spravedlnosti v českých zemských zřízeních doby předbělohorské (se zaměřením na 16. století).“Pp. 101-110 in D. Janiš, K. Malý a J. Pánek (eds.). Vladislavské zř́zeni zemské a počátky ústavního zř́zení v Českých zemich (1500-1619): sbornik príspěvků z mezinárodni konference konané ve dnech 7.-8. prosince 2000 v Praze. Praha: Historický ústav Akademie věd České republiky.

Adamová, Karolina and Ladislav Kř́žkovský. 2003. „Obecné dobré v třetím tisíciletí.“ Pp. 19-31 in V. Mikule (ed.). Pocta Františku Šamalíkovi k 80. narozeninám. Praha: ASPI.

30 Že jde o výpověd’ nadčasovou, potvrzuje nejnovější práce Martina Škopa (2013). 
Alvargonzález, David. 2011. „Multidisciplinarity, Interdisciplinarity, Transdisciplinarity, and the Sciences.“ International Studies in the Philosophy of Science 25 (4): 387-403.

Beránek, Karel et al. 1995. Déjiny Univerzity Karlovy. Sv. II, 1622-1802. Praha: Univerzita Karlova.

Bláhová, Marie. 2009. „Advokacie v českých zemích před rokem 1615.“ Pp. 20-45 in S. Balík et al. (eds.). Dějiny advokacie v Čechách, na Moravě a ve Slezsku. Praha: Česká advokátní komora.

Burke, Peter. 2007. Společnost a vědění. Od Gutenberga k Diderotovi. Praha: Univerzita Karlova.

Čornejová, Ivana et al. 1995. Déjiny Univerzity Karlovy. Sv. I, 1347/48-1622. Praha: Univerzita Karlova.

Darge, Rolf. 2010. „Der Anfang der Interdisziplinarität zwischen Philosophie und Theologie im 13. Jahrhundert.“ Salzburger Jahrbuch für Philosophie 55: 47-65.

De Ridder-Symoens, Hilde a Walter Rüegg. 1992. A History of the University in Europe. Vol. 1, Universities in the Middle Ages. Cambridge: University Press.

De Ridder-Symoens, Hilde a Walter Rüegg. 1996. A History of the University in Europe. Vol. 2, Universities in Early Modern Europe: 1500-1800. Cambridge: University Press.

Dubský, Ivan. 1993. „O ideji univerzity.“ Pp. 71-80 in J. Fiala (ed.). Obnova ideje univerzity: soubor statí o významu a postavení univerzit v současném světě. Praha: Karolinum.

Fiala, Jiří. 1993. Obnova ideje univerzity: soubor statí o významu a postavení univerzit v současném světě. Praha: Karolinum.

Frodeman, Robert, Julie T. Klein a Carl Mitcham. 2010. The Oxford Handbook of Interdisciplinarity. Oxford: University Press.

Grundmann, Herbert. 1976. Vom Ursprung der Universität im Mittelalter. Darmstadt: Wissenschaftliche Buchgesellschaft.

Hammerstein, Notker. 2003. Bildung und Wissenschaft vom 15. bis zum 17. Jahrhundert. München: Oldenbourg Verlag.

Hattenhauer, Hans. 1998. Evropské dějiny práva. Praha: C. H. Beck.

Havel, Ivan M. 1998. Otevřené oči a zvednuté oboči. Praha: Vesmír.

Havel, Ivan M. 2005. Interdisciplinarita, transdisciplinarita a vysokoškolské vzdělávání. Praha: CTS. Retrieved May 26, 2015 (http://www.cts.cuni.cz/soubory/reporty/CTS-05-10.pdf).

Horák, František. 1956. Knihopis českých a slovenských tisků od doby nejstarši až do konce XVIII. století. Díl II, Tisky z let 1501-1800. Část VI. P-Píseň. Praha: ČSAV.

Horský, Jan. 2013. „Formování moderní vědy.“ Pp. 649-669 in M. Šedivá Koldinská, I. Cerman et al. (eds.). Základni problémy studia raného novověku. Praha: NLN.

Horský, Zdeněk. 1980. Kepler v Praze. Praha: Mladá fronta.

Husserl, Edmund. 1996. Krize evropských věd a transcendentálni fenomenologie. Úvod do fenomenologické filozofie. Praha: Academia.

Jantsch, Erich. 1970. „Inter- and Transdisciplinary University: A Systems Approach to Education and Innovation." Policy Sciences 1: 403-428.

Juřicová, Vendula. 2008. Studijní cesty šlechticů z českých zemí na reformované školy v Německu a Švýcarsku na přelomu 16. a 17. století. Diplomová práce. Brno: Masarykova univerzita, Filozofická fakulta, Historický ústav.

Kejř, Jiří. 1995. Dějiny pražské právnické univerzity. Praha: Karolinum.

Kejřr, Jiří. 1996. „Právní kultura českého středověku.“ Minulostí Západočeského kraje 31: 7-25.

Klabouch, Jiřri. 1962. „Die humanistische Jurisprudenz und die Rechtsentwicklung in den böhmischen Ländern." Pp. 279-303 in J. Irmscher (ed.). Renaissance und Humanismus in Mittel- und Osteuropa.

Eine Sammlung von Materialien. II. Band. Berlin: Akademie Verlag.

Klein, Julie T. 1990. Interdisciplinarity: History, Theory, and Practice. Detroit: Wayne State University Press.

Kroupa, Jiří. 1996. Školy dějin uměni: metodologie dějin umění I. Brno: Masarykova univerzita.

Kuhn, Thomas S. 2008. Struktura vědeckých revolucí. Praha: OIKOYMENH. 
Le Goff, Jacques. 1999. Intelektuálové ve středověku. Praha: Karolinum.

Lenz, Werner. 2010. Interdiziplinarität - Wissenschaft im Wandel: Beiträge zur Entwicklung der Fakultät für Umwelt-, Regional- und Bildungswissenschaft. Wien: Erhard Löcker.

Malý, Karel. 2001. „Právní kultura v českém stavovském státě.“ Pp. 55-65 in D. Janiš, K. Malý a J. Pánek (eds.). Vladislavské zřizeni zemské a počátky ústavního zř́zení v Českých zemích (1500-1619): sborník príspěvků z mezinárodni konference konané ve dnech 7.-8. prosince 2000 v Praze. Praha: Historický ústav Akademie věd České republiky.

Martínek, Jan. 1972. „Michal Pěčka z Radostic a Pražská universita.“ Acta Universitatis Carolinae. Historia Universitatis Carolinae Pragensis 12 (1-2): 111-124.

Martínek, Jan. 1983-1984. „Pamfletistická činnost Michala Pěčky z Radostic a její předbělohorské kořeny." Strahovská knihovna 18-19: 117-123.

Neubauer, Zdeněk. 1993. „Univerzita a idea vzdělanosti.“ Pp. 118-168 in J. Fiala (ed.). Obnova ideje univerzity: soubor statí o významu a postavení univerzit v současném světě. Praha: Karolinum.

Pešek, Jiří. 1993. Měštanská vzdělanost a kultura v předbělohorských Čechách 1547-1620. (Všední dny kulturního života). Praha: Univerzita Karlova.

Pešek, Jiří. 1995. „Výuka a humanismus na pražské univerzitě doby předbělohorské.“ Pp. 227-239 in I. Čornejová et al. (eds.). Dějiny Univerzity Karlovy. Sv. I, 1347/48-1622. Praha: Univerzita Karlova.

Petráň, Josef. 1993. „Vzdalování i návraty archetypu univerzitní ideje.“ Pp. 95-103 in J. Fiala (ed.). Obnova ideje univerzity: soubor statí o významu a postaveni univerzit v současném světě. Praha: Karolinum.

Petrů, Eduard. 1996. „Informační exploze 16. století a genologický systém humanistické literatury.“ Pp. 227-232 in E. Petrů (ed.). Vzdálené hlasy: studie o starši české literatuře. Olomouc: Votobia.

Pišna, Jan. 2007. „Opovrhovaný pamfletista Michal Pěčka Smržický z Radostic.“ A2 7 (27): 7.

Pišna, Jan. 2013. „Dílo ,Akcí a rozepře... Michala Pěčky z Radostic jako pocta prokurátorům.“ Pp. 215-223 in E. Šidlovský, V. Valeš a J. Polesný (eds.). Melior est aquisitio scientiae negotiatione argenti: pocta Prof. Ignácovi Antonínovi Hrdinovi, O. Praem. $k$ šedesátým narozeninám. Praha: Královská kanonie premonstrátů na Strahově.

Porter, Roy. 2013. Dějiny medicíny: od starověku po současnost. Praha: Prostor.

Pospíšil, Ctirad V. 2010. Hermeneutika mystéria. Struktury myšlení v dogmatické teologii. Praha: Krystal OP.

Quintilianus, Marcus F. 1985. Základy rétoriky. Praha: Odeon.

Riché, Pierre a Jacques Verger. 2011. Učitelé a žáci ve středověku. Praha: Vyšehrad.

Ř́hová, Milada. 2002. „Středověký lékař.“ Pp. 309-336 in M. Nodl a F. Šmahel (eds.). Člověk českého středověku. Praha: Argo.

Salutati, Coluccio a Peter M. Schenkel. 1990. Vom Vorrang der Jurisprudenz oder der Medizin / De nobilitate legum et medicinae: lateinisch-deutsche Ausgabe. München: Fink.

Seltenreich, Radim. 1996. Právní humanismus jako výraz evropského právního vývoje. Praha: Univerzita Karlova.

Schwarz, Richard. 1974. Wissenschaft als interdisziplinäres Problem. I. Teil. Berlin: Walter de Gruyter. Schwarz, Richard. 1975. Wissenschaft als interdisziplinäres Problem. II. Teil. Berlin: Walter de Gruyter.

Snow, Charles P. 1964. The Two Cultures: And A Second Look. An Expanded Version of The Two Cultures and the Scientific Revolution. New York: New American Library.

Storchová, Lucie. 2003a. „Humanistická komunikace a její sociální rozměr: příspěvek k interpretaci českého renesančního humanismu.“ Časopis Matice moravské 122 (1): 61-97.

Storchová, Lucie. 2003b. „Alžběta Johanna Westonia - rara avis v humanistické res publica litteraria?“ Pp. 149-165 in E. Petrů (ed.). Proměny osudu. Brno: Atlantis. 
Storchová, Lucie. 2011. Paupertate styloque connecti. Utvářeni humanistické učenecké komunity v českých zemich. Praha: Scriptorium.

Svatoš, Michal. 1988. „Humanismus an der Universität Prag im 15. und 16. Jahrhundert.“ Pp. 195-206 in H. Rothe, H.-B. Harder a J. Kolár (eds.). Studien zum Humanismus in den böhmischen Ländern. Köln: Böhlau.

Škop, Martin. 2013. ... právo, jazyk a př́běh. Praha: Auditorium.

Štachová, Nad'a. 2014. „Mezi nadějí a zoufalstvím. K počátkům profesní etiky advokátů v českých zemích." Právník 153 (5): 411-423.

Truhlár̆, Antonín, Karel Hrdina, Josef Hejnic a Jan Martínek. 1973. Rukovět humanistického básnictví $v$ Čechách a na Moravě, Sv. 4. N-̌̌. Praha: Academia.

Urfus, Valentin. 1994. Historické základy novodobého práva soukromého: Ǩímskoprávní dědictví a soukromé právo kontinentálni Evropy. Praha: C. H. Beck.

Varcl, Ladislav et al. 1978. Antika a česká kultura. Praha: Academia.

Vopěnka, Petr. 2003. Úhelný kámen evropské vzdělanosti a moci: souborné vydání Rozprav s geometrií. Praha: Práh.

Weingart, Peter. 2010. „A Short History of Knowledge Formations.“Pp. 3-14 in R. Frodeman, J. T. Klein a C. Mitcham (eds.). The Oxford Handbook of Interdisciplinarity. Oxford: University Press.

Yatesová, Frances. 2009. Giordano Bruno a hermetická tradice. Praha: Vyšehrad.

\section{Autorka}

Nad'a Štachová působí jako odborná asistentka na Katedře dějin státu a práva Právnické fakulty MU v Brně. Dlouhodobě se zabývá studiem českého středověkého zemského práva, zejména právních knih. $\mathrm{V}$ posledních letech se zaměřuje na dějiny advokacie v českých zemích a v této souvislosti na rozbor literárních a normativních pramenů z přelomu středověku a raného novověku. Mezi jiným sleduje z pohledu právních dějin vztah mezi normou a uzancí, kořeny interdisciplinarity a etický rozměr výkonu právnických profesí.

Kontakt: nada.stachova@email.cz 